\title{
In-Service Professional Development on Supporting Elementary Teachers' Pedagogical Content Knowledge and Efficacy through Inquiry-Based Teacher Training
}

\author{
Muhammad Randy Fananta, ${ }^{1, *}$, Tria Umbara ${ }^{2}$, and Saktiana Dwi Hastuti ${ }^{1}$ \\ ${ }^{1}$ PT. KUARK Internasional, Jakarta, Indonesia \\ ${ }^{2}$ Elemetary Teacher Education, President University, Cikarang, Indonesia
}

\begin{abstract}
This study was conducted to ascertain the role of inquiry in supporting teachers' pedagogical content knowledge (PCK) and efficacy based on the In-Service Profesional Development (INSEP) findings. INSEP program has been conducted by Kelas Lentera Kuark in East Sumba Regency, East Nusa Tenggara Province. This program was conducted from January to July of 2016 within three stages such as: (1) Preliminary assessment (2) Teacher training (consist of two sessions: Motivational and leadership training, and Inquiry-Based Teacher Training); (3) Monitoring and Evaluation. This study was conducted using the qualitative approach of multiple cases study. The data were obtained from multiple sources and analyzed through the approach of constant comparative method. The findings show that inquiry plays an important role in constructing teachers' PCK and efficacy. Inquiry does not only serves as an instructional teaching but also it develops their paradigm to understand more about Nature of Science thus they have the ability to develop PCK that can bring a direct impact to their efficacy. Keywords: PCK, efficacy, inquiry, teacher training, professional development science, nature of science
\end{abstract}

\section{Introduction}

Based on the initial surveys' result towards elementary teachers in East Sumba Regency of East Nusa Tenggara Province in Indonesia, it was found the fact that teachers are still the center of science learning process where they deliver it through lecturing and recitation. Teachers express that they have lack of confidence in delivering science materials. They find it difficult to gain the students' interest to study science subject. The reason behind it is because they have not enough capacity of pedagogical content knowledge (PCK).

PCK correlates with the teachers' knowledge based on experience time to time regarding the (1) content knowledge needed; (2) strategy of pedagogy and teaching to gain

*Corresponding author: randy.fananta@komikuark.net 
the students' attention; (3) the knowledge about students intelligence background and experience, therefore they can facilitate the students to learn and develop the understanding about the conceptual knowledge from the particular matter $[1,2,3,4]$. To develop PCK, science teachers need the knowledge about science material, general pedagogy and context (students and school environment) where the particular teachers work [5]. In this case, teachers may not be able to integrate the nature of science as a whole when delivering the teaching. Regarding its integration, teachers need to believe on their professional capacities (known as teacher efficacy). Teacher efficacy in teaching can be used as a powerful indicator from teachers' professional behavior in class $[6,7]$. Teachers with low efficacy will struggle more in teaching, satisfaction under the standard, high level of stress at work [7]. The improvement of teachers' professionalism at teaching has a strong impact to teacher efficacy [8]. Therefore, the improvement of teacher efficacy can be done by increasing teachers' PCK through In-Service Professional Development (INSEP) program

Ministry of Education and Culture of the Republic of Indonesia [9] has established the policy in implementing the national curriculum which is expected to strengthen the scientific approach through the application of learning based on inquiry process. This process is an activity for students to improve their knowledge and understanding of scientific ideas and how scientists learn about the nature [10, 11]. Inquiry has been regarded as an approach to bridge the gap between a scientist's way of doing science and a students' learning of science [12].

However, yet there is no teacher training model that integrates inquiry as an approach in East Sumba. We (Kelas Lentera Kuark) have designed inquiry-based teacher training that was proper in supporting teachers' PCK in Tabalong, South Kalimantan [13]. This program was conducted into three stages i.e. (1) Preliminary assessment (2) Teacher training (consist of two sessions: Motivational and leadership training, and Inquiry-Based Teacher Training); (3) Monitoring and Evaluation. Furthermore, we found that the training of delivering science material through inquiry-based learning has given a direct experience to understand the application of inquiry for teaching in class. In this case, we tried to apply the model to another setting and circumstance in order to strengthen the impact of the model on teachers' PCK and efficacy.

\section{Methods}

This study was conducted using a qualitative approach through a multiple case study. The multiple-case study was conducted to four participants of elementary school teachers in East Sumba, East Nusa Tenggara that participated in INSEP program with inquiry-based teacher training model within the period of January to July of 2016. The data of the participants were presented on Table 1.

Table 1. Background information of the participants of INSEP program.

\begin{tabular}{|l|c|c|c|}
\hline Participant Name & $\begin{array}{c}\text { Age } \\
\text { (years) }\end{array}$ & Education & $\begin{array}{c}\text { Teaching } \\
\text { Experience }\end{array}$ \\
\hline Magdalena Kana & 54 & $\begin{array}{c}\text { Sekolah Pendidikan Guru } \\
\text { (equal to Senior High School) }\end{array}$ & 33 years \\
\hline Mardiana Radjah & 40 & Diploma 1 English & 12 years \\
\hline Sri Mimiasti & 30 & Diploma 2 Elementary Education & 6 years \\
\hline Yuliana Mehang & 40 & Bachelor of Elementary Education & 7 years \\
\hline
\end{tabular}

The case study focuses on two things which are: PCK and teachers' efficacy. Teachers' efficacy can be revealed using the instrument of a list of questions which can uncover the certainty and development to organize the concept from how that certainty represents the daily habit [14]. As the triangulation, we conducted a semi-structured interview with teachers. 
PCK is the combination of teaching, learning, and content [2]. Teachers' expertise in science content was measured through pre-test and post-test. Teaching and learning method were disclosed from multiple sources including classroom observation, lesson plan, teacher written reflection, and semi-structured interview. Non-participant observation method was also conducted during the INSEP process inside and outside the class.

All the data of interview and observation were recorded and transcribed verbatim. The collected data were then coded word per word. Then they were analyzed using the constant comparative method approach. Within this research, the coded data of transcribed interview and observation were compared day by day to identify the pattern that appeared during the process of training and monitoring. The result from each data was connected to one another in order to obtain the whole conclusion regarding the efficacy and PCK of each teacher.

\section{Results and Discussion}

We conducted the inquiry-based teacher training where teachers are not only trained to deepen their science competency but also to create the subject specific pedagogy in teaching science and also doing the simulation for the implementation. There are three stages of the inquiry-based teacher training which can be seen in Fig. 2.

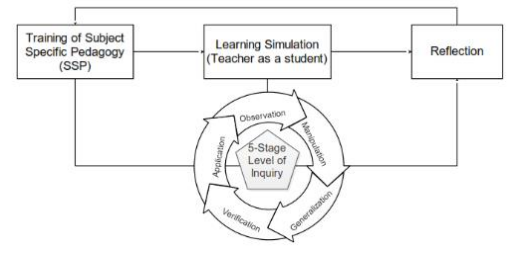

Fig.2. Inquiry-based sub-training [13]

The first stage is introducing the model of instructional inquiry-based learning and SSP of inquiry, then conducting the inquiry learning simulation with teachers where they position themselves as students who perform the inquiry-based learning. In this stage the teachers conducted the inquiry-based learning as observation, manipulation, generalization, verification, and application. Lastly, the teachers conducted a reflection from the learning process to comprehend more when implementing the inquiry-based learning within the national curriculum. Within this stage, we conducted the pre- and post-test to see the increase of competency based on the gain score in each stage. The result of the pre-and post-test can be seen on Table 2.

Table 2. Result of Pre-and Post-Test about Science Competency

\begin{tabular}{|l|c|c|l|c|c|l|}
\hline \multirow{2}{*}{ Teacher Name } & \multicolumn{3}{|c|}{ First Session } & \multicolumn{3}{c|}{ Second Session } \\
\cline { 2 - 7 } & Pre-test & Post-test & Gain (category) & Pre-test & Post-test & Gain (Category) \\
\hline $\begin{array}{l}\text { Magdalena } \\
\text { Kana }\end{array}$ & 14,71 & 55,64 & 0,48 (Mediocre) & 28,95 & 80,15 & 0,72 (High) \\
\hline Mardiana Radja & 38.24 & 46.57 & 0,13 (Low) & 42,87 & 86,84 & 0,77 (High) \\
\hline Sri Mimiasti & 29.41 & 67.89 & 0,55 (Mediocre) & 53,50 & 92,11 & 0,83 (High) \\
\hline $\begin{array}{l}\text { Yuliana } \\
\text { Mehang }\end{array}$ & 17,65 & 36,03 & 0,22 (Low) & 34,65 & 78,51 & 0,67 (Mediocre) \\
\hline
\end{tabular}

During the process, the better improvement shows after the second training was conducted. This means they have absorbed a good understanding of science knowledge. This suggests that the inquiry approach is particularly suitable in developing teachers' content knowledge. This is in line with the previous study which revealed that inquirybased learning conducted by applying a systematic scientific method can build the logical and analytical thinking skills $[15,16,13]$ with the result that teacher was easier to understand the content which had been delivered. 
The components of the teachers' PCK in teaching science is related with five things such as: (1) orientation in science teaching; (2) knowledge of science curriculum; (3) knowledge of students understanding of science; (4) knowledge of instructional strategy; and (5) knowledge of assessment of scientific literacy [17, 18, 19]. Based on the result of interview and reflection, we can see that there is a shift on their point of views regarding the orientation of science teaching and some of those findings can be seen on Table 3 .

Table 3. The Impact of INSEP on Teachers' Science Teaching Orientation.

\begin{tabular}{|c|c|}
\hline $\begin{array}{l}\text { Magdalena } \\
\text { Kana }\end{array}$ & $\begin{array}{l}\text { "... Before we used to learn strictly from the book. But now we can use any material around our } \\
\text { school to learn" (Post-Interview) }\end{array}$ \\
\hline $\begin{array}{l}\text { Mardiana } \\
\text { Radja }\end{array}$ & $\begin{array}{l}\text { "...I used to teach what's on the book, that's it. Then after we applied (inquiry base learning), the } \\
\text { impact has increase our students' interest..." (Post-Interview) } \\
\text { "...Students are more enthusiastic and enjoy... Seeing their behavior and activity sometimes have } \\
\text { given me new ideas to be applied for the next class." (Teachers' reflection) }\end{array}$ \\
\hline $\begin{array}{l}\text { Sri } \\
\text { Mimiasti }\end{array}$ & $\begin{array}{l}\text { "... Before I used to teach by preaching and giving more material. But after I attended Kelas } \\
\text { Lentera Kuark, the way I teach is more interesting and fun..." (Teachers' reflection) }\end{array}$ \\
\hline $\begin{array}{l}\text { Yuliana } \\
\text { Mehang }\end{array}$ & $\begin{array}{l}\text { "... Creative science material is very compatible with curriculum of 2013(Indonesians' National } \\
\text { Curriculum) ..." (Teachers' reflection) } \\
\text { "...The impact of this training is not only in science but can also bring into other course such as } \\
\text { social science in market session or in theater..." (Post-Interview) }\end{array}$ \\
\hline
\end{tabular}

Understanding PCK in teaching science is easier to shape by giving a direct experience to teachers as students learn in class and by exploring and analyzing the relationship between content, teaching and learning [2]. Through the simulation inquiry-based learning in giving the concept of science and reflection, teachers have come to a different point of view in teaching science. From the post-interview and teacher reflection, it was shown that teachers had a new orientation to teaching science. Besides that, the teachers had a good understanding about the implementation of science curriculum in their class.

Teachers' efficacy has a strong correlation in understanding PCK [19]. This can be seen from the questionnaire result on the belief in becoming a professional educator in teaching science, as shown in Table 4. It shows that the teachers have a good efficacy in teaching science and a strong belief in self-improvement. This result indicates that the teachers have the willingness to be professional learners after INSEP. This also shows that having such belief is not related to the age nor educational background which can be seen in Kana case. In one hand, this finding strengthens the theory of teachers' efficacy which is very crucial to their understanding of PCK. On the other hand, however, the teachers have less confident in improving the assessment. After all, this finding indicates their lack in constructing the assessment instrument especially based on process skills.

Table 4. Teachers' Efficacy after INSET.

\begin{tabular}{|l|c|c|c|c|}
\hline \multirow{2}{*}{ Aspect } & \multicolumn{4}{|c|}{ Teacher Name } \\
\cline { 2 - 5 } & Magdalena Kana & Mardiana Radja & Sri Mimiasti & Yuliana Mehang \\
\hline $\begin{array}{l}\text { Implementing inquiry } \\
\text { base learning }\end{array}$ & $84 \%$ (Very confident) & $66 \%$ (confident) & $\begin{array}{l}83 \% \text { (very } \\
\text { confident) }\end{array}$ & $80 \%$ (confident) \\
\hline Being a facilitator & $88 \%$ (very confident) & $75 \%$ (confident) & $\begin{array}{l}85 \% \text { (very } \\
\text { confident) }\end{array}$ & $75 \%$ (confident) \\
\hline Being a Motivator & $85 \%$ (very confident) & $75 \%$ (confident) & $\begin{array}{l}90 \% \text { (very } \\
\text { confident) }\end{array}$ & $\begin{array}{l}85 \% \text { (very } \\
\text { confident) }\end{array}$ \\
\hline $\begin{array}{l}\text { Thinking skill } \\
\text { training }\end{array}$ & $85 \%$ (very confident) & $70 \%$ (confident) & $\begin{array}{l}85 \% \text { (very } \\
\text { confident) }\end{array}$ & $75 \%$ (confident) \\
\hline $\begin{array}{l}\text { Becoming expert on } \\
\text { science }\end{array}$ & $93 \%$ (very confident) & $70 \%$ (confident) & $\begin{array}{l}85 \% \text { (very } \\
\text { confident) }\end{array}$ & $78 \%$ (confident) \\
\hline Class management & $90 \%$ (very confident) & $75 \%$ (confident) & $\begin{array}{l}85 \% \text { (very } \\
\text { confident) }\end{array}$ & $85 \%$ (confident) \\
\hline $\begin{array}{l}\text { Assessment } \\
\text { development }\end{array}$ & $73 \%$ (confident) & $\begin{array}{l}60 \% \text { (less } \\
\text { confident) }\end{array}$ & $80 \%$ (confident) & $70 \%$ (confident) \\
\hline Self-improvement & $90 \%$ (very confident) & $\begin{array}{l}90 \% \text { (very } \\
\text { confident) }\end{array}$ & $\begin{array}{l}90 \% \text { (very } \\
\text { confident) }\end{array}$ & $80 \%$ (confident) \\
\hline
\end{tabular}




\section{Conclusion}

The INSEP program can bring a positive impact for science content, teachers' PCK and efficacy as well as its correlation with the inquiry. The internalization of inquiry plays an important role in connecting teachers' understanding of nature of science and the instructional strategy in their class, and also crucial for teachers in developing their paradigm in improving their professionalism [20,21]. INSEP integrated with the inquiry process through learning simulation enables teachers to build the understanding of science as well as gaining the knowledge of instructional strategy of inquiry-based learning.

Inquiry improved teachers' self-efficacy indirectly by developing their science knowledge and pedagogy [22]. The development of inquiry in improving teachers' PCK and efficacy can be seen in Figure 3 . The correlation between inquiry-based learning training for teachers with the development of their PCK and efficacy can be seen where inquiry is the ultimate key in INSEP program. Inquiry has opened a new point of view for teachers where it enables them to understand more about science curriculum, students' ability in understanding science, instructional strategy and valuing science literacy where these lead to the change of science teaching orientation.

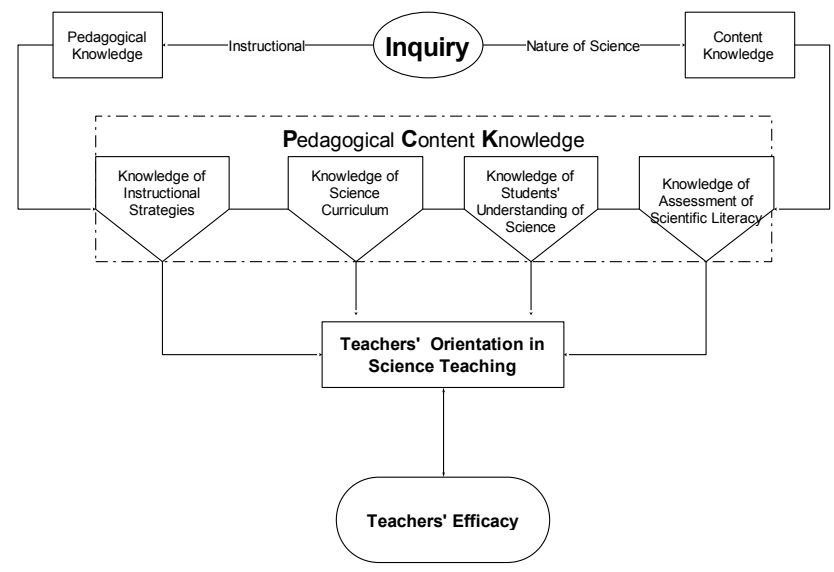

Fig.3. Framework of Inquiry on Supporting Teachers' PCK and Efficacy

There are several implications for further research and science teacher education. This result shows that inquiry plays an important role in shaping and building teachers' PCK and efficacy specifically in teaching science. This finding can help teachers, educators, researcher, and the policy makers in developing the most suitable trainings for elementary teachers to focus on the professionalism. Elementary teachers were always given a very general science training where it raises the possibility of them having a lower PCK than high school teachers [23]. Therefore, INSEP should be set as a sustainable program.

There are still some improvements that need to be added to the INSEP that has been given such as assessment skills based on science literacy. Even though teachers have noted it down within their lesson plan, they are still having lack of confidence in assessment development. Interactive assessment [24] is used during the interaction between teachers and students using the concept of map in science learning [25] which can be applicable for the INSEP program and fascinating to be researched for its easiness and effectiveness for short term training. With the high scores in assessment development of teachers' efficacy, thus we hope the entire PCK components can be built within their mind. 
The authors would like to thank PT Kuark Internasional for the support in making this research possible. Many thanks to IOA that conducted the in-service teacher professional development in East Sumba Regency, East Nusa Tenggara, Indonesia.

\section{References}

1. D. C. Smith, JSTE, 11(1), 27-46, (2000)

2. J. Loughran, A. Berry and P. Mulhall, Understanding and Developing Science Teachers' Pedagogical Content Knowledge (Rotterdam, 2012)

3. A. L. Gardner and J. Gess-Newsome, A PCK rubric to Measure Teachers' Knowledge of Inquiry-Based Instruction Using Three Data Source (NARST, 2011)

4. J. Gess-Newsome, A Model of Teacher Professional Knowledge and Skill Including PCK Results of The Thinking From The PCK Summit, in Re-Examining Pedagogical Content Knowledge, A. Berry, P. Friedrichsen and J. Loughran, Eds., 28-42, (2015)

5. R. M. Schneider and K. Plasman, RER, 81(4), 530-565, (2011)

6. C. Velthuis, P. Fisser and J. Pieters, JSTE, 445-464, (2014)

7. R. M. Klassen, V. M. C. Tze, S. M. Betts and K. A. Gordon, Educ Psychol, 21-43, (2011)

8. L. Beauchamp, R. Klassen, J. Parsons, T. Durksen and L. Taylor, Exploring the Development of Teacher Efficacy Through Professional Learning Experiences (Alberta Teachers' Association,2014)

9. Ministry of Education and Culture of the Republic of Indonesia, Lampiran Permendikbud Nomor 22 Tahun 2016, Retrieved from http://bit.ly/2ikM1Hq

10. R. D. Anderson, JSTE, 13(1), 1-12, (2002)

11. Alberta Learning, Focus on Inquiry, (Edmonto, 2004)

12. M. Kim, K. Juuti, J. Holbrook and M. Rannikmäe, IJSME, 11, 359-383, (2013)

13. T. Umbara, M. R. Fananta and S. D. Hastuti, ASSEHR, 57, 189-194, (2017)

14. I. M. Riggs and L. G.Sci. Ed., 74(6), 625 - 637, (1990)

15. C. J. Wenning, JPTEO, 6(2), 9-16, (2011)

16. C. Rooney, EJOLTS, 5(2), 99-127, (2012)

17. L. S. Shulman, Harvard Educational Review, 57(1), 1-22, (1987)

18. S. Magnusson, J. Krajcik and H. Borko, Nature, Sources, and Development of Pedagogical Content Knowledge for Science Teaching, in PCK and Science Education, (J. Gess-Newsome and N. G. Lederman, 1999)

19. S. Park and S. J. Oliver, Res Sci Educ, 261-284, (2008)

20. V. L. Akerson and D. L. Hanuscin, JRST, 44(5), 653-680, (2007)

21. P. Nuangchalerm, Higher Education Studies, 2(2), 66-71, (2012)

22. S. Choi and Y. H. Lee, 초등과학교육 제34권 제4호, 406-418, (2015)

23. M. M. Thomson, D. DiFrancesca, S. Carrier and C. Lee, Teacher Development, 1-18, (2016)

24. B. Cowie and B. Bell, Assessment in Education, 6(1), 101-116, (1999)

25. T. Stoddart, R. Abrams, G. Erika and C. IJSE, 22(12), 1221-1246, (2000) 